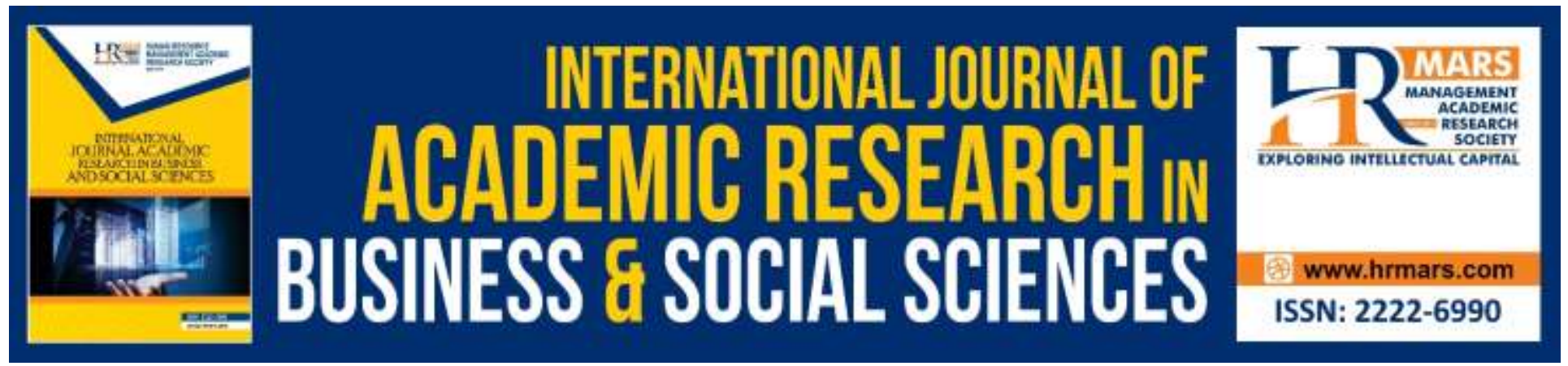

\title{
Development of WebOPAC Training Information Literacy Scale
}

Mohd Nasir Ismail, Nurfaezah Mamat

To Link this Article: http://dx.doi.org/10.6007/IJARBSS/v9-i13/6865

DOI: 10.6007/IJARBSS/v9-i13/6865

Received: 22 June 2019, Revised: 19 July 2019, Accepted: 02 August 2019

Published Online: 23 September 2019

In-Text Citation: (Ismail \& Mamat, 2020)

To Cite this Article: Ismail, M. N., \& Mamat, N. (2020). Development of WebOPAC Training Information Literacy Scale. International Journal of Academic Research in Business and Social Sciences, 9(13), 368-388.

Copyright: (c) 2019 The Author(s)

Published by Human Resource Management Academic Research Society (www.hrmars.com)

This article is published under the Creative Commons Attribution (CC BY 4.0) license. Anyone may reproduce, distribute, translate and create derivative works of this article (for both commercial and non-commercial purposes), subject to full attribution to the original publication and authors. The full terms of this license may be seen

at: http://creativecommons.org/licences/by/4.0/legalcode

Special Issue: Revolutionizing Education: Challenges, Innovation, Collaboration, 2019, Pg. 368 - 388 http://hrmars.com/index.php/pages/detail/IJARBSS

JOURNAL HOMEPAGE

Full Terms \& Conditions of access and use can be found at http://hrmars.com/index.php/pages/detail/publication-ethics 


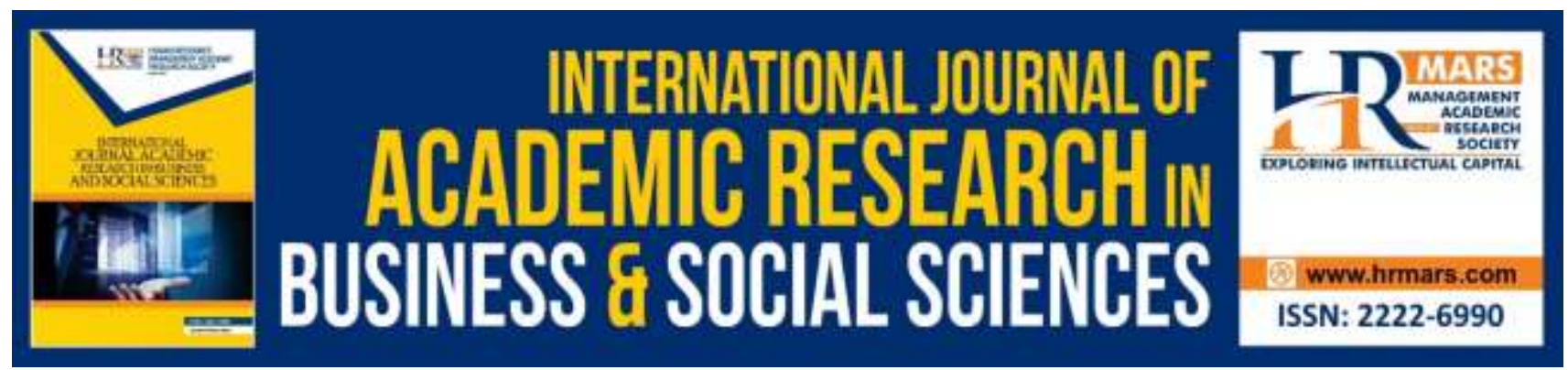

\title{
Development of WebOPAC Training Information Literacy Scale
}

\author{
Mohd Nasir Ismail, Nurfaezah Mamat \\ Faculty of Information Management, Universiti Teknologi MARA, Malaysia
}

\begin{abstract}
Many studies proved that WebOPAC training during library orientation programs contributes most to individual's information literacy skills development. The irony is that there is no standard measurement on this WebOPAC training which measures the scores of information literacy skills. Therefore, the purpose of this study is to develop a scale to measure the information literacy skills for WebOPAC training. This scale is based on standard one, standard two, standard three and standard five of the Association of College and Research Libraries (ACRL) information literacy competency standards which is expected to assist institutions in identifying library users' ability to locate, evaluate, and use information effectively when it is needed. Information literacy competency standards of the instrument were tested with a group of thirty (30) first year degree students. Exploratory factor analysis and Cronbach's alpha internal reliability coefficient were used to measure reliability and validity of the scale. Finally, a valid and reliable 28-item WebOPAC training information literacy scale was developed which could be a guideline to future information professionals, librarians, and researchers in measuring individual's information literacy skills during WebOPAC teaching and learning sessions.
\end{abstract}

Keywords: ACRL Standards, Information Literacy, Instrument, Library Orientation, WebOPAC Training

\section{Introduction}

The library has become a central part of the student learning, development, and success. The objective of any library is to disseminate important information and to make an effective use of its resource to the library user. To use the library efficiently, the users should be well versed on the availability of different sources within the library and thus be able to reach for the required sources in the library efficiently. Generally, Malaysian academic libraries of each universities were actively conducting their various library orientation programs, library skill trainings, library research trainings, information skills trainings and other similar trainings whose main aim was to educate the user on information use (Ramli, Fun, \& Idris, 2009; Kim \& Shumaker, 2015).

Information literacy (IL) is an umbrella term which encompasses concepts such as digital, visual and media literacy's, academic literacy, information handling, information skills, data duration and data 
INTERNATIONAL JOURNAL OF ACADEMIC RESEARCH IN BUSINESS AND SOCIAL SCIENCES

Vol. 9, No. 13, Special Issue: Revolutionizing Education: Challenges, Innovation, Collaboration., 2019, E-ISSN: 2222-6990 @ 2019 HRMARS

management (Information Literacy Standards Committee, 2012; Shao \& Purpur, 2016). In addition, Baro and Keboh (2012) and Saunders, Severyn, Freundlich, Piroli, and Munderback (2016), reported that IL was recognized worldwide as an essential skill for the information society. They concluded that academic students should not only be able to recognize information when it is needed but student should also will be able to identify, locate, evaluate and effectively use the information need for decision making or learning process.

\section{Information Literacy}

Information literacy (IL) is one of the critical digital-age literacies for higher education. Thanuskodi (2013) and Kim and Shumaker (2015) defined that IL is a way to motivate students to access, use, evaluate the information more effective, and the skills themselves as more important for academic success. Therefore, academic libraries stretch to the library orientation programs improvement to develop information literacy skill among undergraduates as envisioned in Malaysian Vision 2020 (Edzan, 2008; Jyoon \& Ibrahim, 2015). Thus, student needs to be information literate to cope with the challenges in further studies and future profession.

Regarding to Ranaweera (2010), Baroutian and Kensington-Miller (2015) and Grau, Archambault, Acosta and Mclean (2016) defined that IL as gaining the necessary skills required to access process and present information for learning, research, problem solving and career development. Although there are several variations of concepts used and discussed, but generally Association of College and Research Libraries (ACRL, 2011) well-defined that IL is a set of abilities requiring individuals to recognize information need and have ability to locate, evaluate, and use needed the information effectively. These standards are considerably the most acceptable standards to measure IL competencies in institution of higher education worldwide (Mittermeyer \& Quirion, 2003; Syamalamba, 2011; Rohatgi, Scherer \& Hatlevik, 2016; Shao \& Purpur, 2016).

In additional, IL is not just the ability to find and evaluate information but IL is a collection of experiences, skills and dispositions that encourage the students to use and create the information in the daily tasks. IL is the lifelong learning to all disciplines, to all learning environments and to all scores of education (Cordell, 2013; Thanuskodi, 2013; Fister, 2015; Lanning \& Mallek, 2017). Hence, the assessment of student's information skills is important to determine how information literate their skills and evaluate the quality and usefulness of information resources (Ali, Abu-Hassan, Md Daud, \& Jusoff, 2010; Forster, 2013; Shao \& Purpur, 2016). Historically, IL education was initiated by academic librarians who used several approaches to develop IL among students. Today, academic library as the learning center in each university, does not just collect, preserve, and organize the information, but it also conducts the teaching, research, and creates the knowledge (ACRL, 2014). Moreover, the academic library helps the students to develop manageable skills such as critical thinking and effective communication, which are more needed in education and career field (Jyoon \& Ibrahim, 2015; Shao \& Purpur, 2016).

The Association of College and Research Libraries (ACRL) provided a standard which is known as Information Literacy Competency Standards for Higher Education. This standard is a guideline that can be employed to assist student in learning how to use the information, describe, locate, satisfy, 
INTERNATIONAL JOURNAL OF ACADEMIC RESEARCH IN BUSINESS AND SOCIAL SCIENCES

Vol. 9, No. 13, Special Issue: Revolutionizing Education: Challenges, Innovation, Collaboration., 2019, E-ISSN: 2222-6990 @ 2019 HRMARS

evaluate and use the information effectively. The information literacy standards for higher education which based on the ACRL's framework are shown in Table 1.

Table 1: Information Literacy Standards for Higher Education

\begin{tabular}{ll}
\hline Scales & Details \\
\hline Standard 1 & Deteremining the extent of the nature and information needs \\
Standard 2 & $\begin{array}{l}\text { Accessing needed information effectively and efficency } \\
\text { Evaluating information and its sources crtically and incorporating } \\
\text { Standard 3 }\end{array}$ \\
information into a personal knowledge base and value system \\
Standard 4 & $\begin{array}{l}\text { Using information effectively to accomplish a specifc purpose } \\
\text { Understanding the economic/social/ legal issues surrounding } \\
\text { information use and using information accordingly }\end{array}$ \\
\hline
\end{tabular}

Based on Table 1, the Information Literacy Standards for Higher Education (ACRL, 2014, 2011, 2000) are consists of five standards and twenty-two performance indicators. The standards focus upon the student requirements in higher education at all levels (Team, 2009; Mackey \& Jacobson, 2011; Anunobi \& Udem, 2014). Therefore, the institutions need to identify different levels of thinking skills which related to various learning outcomes in implementing these standards (Gross \& Latham, 2009; ACRL, 2011; Maitaouthong, Tuamsuk \& Tachamanee, 2012). The standards also assessing the list of outcomes toward student progress in their information literacy skills. Studies on Bloom's Taxonomy of Educational Objectives (Lorin \& Krathwohl, 2001; ACRL, 2011) suggested that suitable assessment methods on thinking skills which related to each outcome should be identified as an integral part of the institutions implementation plan in assessing IL skills. Therefore, ACRL (2014) and Wilson (2016) identified the scores of IL skills for standard one (1) and standard two (2) can be categorized as 'lower order' thinking skill while for the standard three (3), standard four (4) and standard five (5) are categorized as 'higher order' thinking skill.

Swain, Sundre, and Clarke (2014) suggested that only standard one, standard two, standard three and standard five are used to measure IL skills among college and graduate school students. Standard four will not be addressed, as this competency is not easily measured by a multiple-choice test. Standard four refers to the student's ability to use the information effectively to accomplish a specific purpose and it would be more reasonably assessed through review of student developed products, processes and performances (Enterprises, 2012; Swain et al., 2014). Therefore, in this study, the development of the IL scale will be based on standard one, standard two, standard three and standard five of the ACRL's information literacy competency standards.

\section{Statement of the Problem}

Recent studies found that few problems facing during practicing information literacy training which relate to the ineffective way and strategy of conducting library tours, introductory information skills classes, and in teaching advanced information skills. As the result, the information literacy training during the orientation sessions does not comply with ACRL's standards (Shao \& Purpur, 2016; Derakhshan, Hassanzadeh, \& Nazari, 2015; Nurfaezah Mamat, Mohd Nasir Ismail \& Adnan Jamaludin, 2014; Magnuson, 2013; Baro \& Keboh, 2012; Husaini, Aziz, Karim, Jamin \& Saad, 2011; Syamalamba, 
INTERNATIONAL JOURNAL OF ACADEMIC RESEARCH IN BUSINESS AND SOCIAL SCIENCES

Vol. 9, No. 13, Special Issue: Revolutionizing Education: Challenges, Innovation, Collaboration., 2019, E-ISSN: 2222-6990 @ 2019 HRMARS

2011; Gullikson, 2006). Studies by Nurfaezah Mamat et al. (2014), Rice and Gregor (2013) and Gregory and Broussard (2011) concluded that the ineffective way and strategy of conducting these orientations programs contribute to the deficiencies of information literacy skill among university students.

According to the needs assessment carried out by Nurfaezah Mamat et al. (2014), they concluded that there was no standardized instrument to test or questionnaire given to the students in order to measure user's understanding of information and knowledge in library skills and expectation of the training quality. A previous studies by Martin (2013), Loo, Eifler, Smith, Pendse, He, Sholinbeck and Dupuis (2016) and Michalak, Rysavy and Wessel (2017), supported that there was no standardized measurement on the library orientation was done to the first year students in higher education, with each librarian focusing on different skills, covering different information and requiring different scores of interaction and participation development process. As well in Malaysia, it still do not have specific measuring instrument of information literacy standards to determine the students competency levels (Wu \& Ssu-Tsen, 2012; Shariman, Razak, \& Noor, 2014; Ukachi, 2015). Thus, the aim of this study is to develop a scale to measure information literacy skills for WebOPAC training.

\section{Instrumentation and Data Collection}

This section discusses the procedures of the development and validation of the scale.

\section{Development of the WebOPAC Training Assessment Information Literacy Scale}

This study aims to develop WebOPAC training information literacy scale that is based on ACRL's information literacy standards. The development of the scale took place in several empirical phases which based on study by Erfanmanesh, Abrizah, \& Karim (2012). The first step involved the development of a list of key components concerning on the constructs of the instrument. For this purpose, potential components were gleaned from several sources: (a) literatures in the areas of information literacy skills, WebOPAC services, information literacy process, and other related areas; (b) existing problems on information literacy skills development; (c) interviews with five (5) expert librarians and twenty (20) degree students to identify what made them anxious when they were used the WebOPAC services which related to the information literacy skills. These expert librarians were random selected from twenty (20) academic libraries in Malaysia. Comments from these expert librarians were also solicited in the development of the key components. As a result, a group of sixty (60) key components was formulated by the researchers regarding to the ACRL's information literacy standards. Figure 1 below shows the procedures of the development and validation of the WebOPAC training information literacy scale based on the ACRL's information literacy standards. 
INTERNATIONAL JOURNAL OF ACADEMIC RESEARCH IN BUSINESS AND SOCIAL SCIENCES

Vol. 9, No. 13, Special Issue: Revolutionizing Education: Challenges, Innovation, Collaboration., 2019, E-ISSN: 2222-6990 @ 2019 HRMARS

\begin{tabular}{|c|}
\hline 1. Develop a list of key components \\
\hline \\
\hline 2. Send to a panel of experts for validation \\
\hline 3. Examine the responses and edit the list of key components \\
\hline 4. Develop a list of statements according to the list of key components \\
\hline \\
\hline \\
\hline \\
\hline
\end{tabular}

Figure 1: Procedures of the Development and Validation of the Scale

The initial list of key components was sent to a panel of experts for validation. Ten (10) panelists in the area of WebOPAC training and information literacy skills were selected to participate in the study. The criterion for selection of the experts included their experiences in conducting the WebOPAC and information literacy trainings during library orientation program. These ten (10) experts were chosen randomly from twenty (20) academic libraries in Malaysia which have more than ten (10) years working experience. Of the ten (10) experts, six (6) are Master Degree holders in library management and four (4) are degree holders in library management. All experts were contacted personally by email and telephone call and they were requested to participate in the study. The list of key components was then sent to them to elicit their expert opinions and comments on those key components. The experts were given two (2) weeks to give their respond. Responses were received from seven (7) experts out of ten (10). Any component that was eliminated by more than one (1) expert was removed from the list. Also, any new component that was suggested by at least one (1) expert was added to the list. Based upon the expert's comments and review, fifty (50) out of sixty (60) key components was approved, while ten (10) components were rejected. As a result, the revised list of key components was developed, which came total of fifty (50) items.

In the next stage of the study, a list of statements was created based on the fifty (50) key components. As mentioned earlier, only ACRL's standard one, standard two, standard three and standard five are used to guide and develop the statements. Standard four will not be addressed, as this competency is not easily measured by a multiple-choice test. This standard four refers to the ability of students to 
use the information effectively to accomplish a specific purpose, the concern would be more reasonable assessed through examination or presentation of products produced by the students (Enterprises, 2012; Wise, Cameron, Yang, \& Davi, 2011). The list of statements then was submitted again to the same panel of experts for validation. They were given two (2) weeks to respond to the new list of items and return their comments, modifications and suggestions. Respond were received from five (5) experts out of seven (7) which incorporated several changes and modifications. The statements were then edited based on feedback from the experts. Based upon the experts' comments and review, forty (40) out of sixty (50) components was approved, while ten (10) components were rejected. Accordingly, forty (40) items were slightly forwarded for clarify.

Following revision to the list of statements, a pilot instrument was developed in order to determine its potential validity. The pilot instrument consisted of forty (40) questions which are six (6) items from Standard One, fourteen (14) items from Standard Two, fifteen (15) items from Standard Three and five (5) items from Standard Five. Also, demographic items were developed to collect essential information of the respondents in this study. The following items of demographic information were collected which are age, gender, field of study, SPM's result, faculty, frequency of WebOPAC service usage in the library.

The next step was the determinations of instrument's content validity and face validity. The panel of experts was asked again to review the pilot instrument whether the instrument be able to measure what is intended to be measured. Five (5) out of seven (7) experts evaluated the content validity of the instrument and confirmed that the statements of the instrument appeared to measure the concept of information literacy skills. Twenty (20) degree students from different faculties at the UiTM Kelantan branch were participated to evaluate the face validity of the pilot instrument. The refinement of items based on the participant's judgment that the indicator really measures the thing it is supposed to measure. This procedure may improve response rates and enhance the validity of the data. After receiving feedbacks and suggestions of the statements from the participants, the statements were revised and the pilot instrument was finalized.

Consequently, the pilot study was conducted in March 2014 at the UiTM Kelantan branch. Participants were thirty five (35) first year degree students. Convenience sampling method was used to select the participants and the instrument was distributed personally by the researcher. The students were informed that their participation was voluntary and that their responses would be used only for academic purposes. They were asked to respond to the pilot instrument which consisted of forty (40) questionnaires and return it to the researcher. The instrument was eight (8) pages long and took about one (1) hour to complete. A cover letter was attached to the questionnaire, which explained the purpose of the study, asked for cooperation, and provided some instruction for completing the questionnaire. Fifty-seven percent (57\%) were female and forty-three percent (43\%) were male. Finally, the participants are from different areas of study which are art, humanities and social sciences (67\%) and science and technology (33\%).

The returned questionnaires then were reviewed for completeness and usability and were coded for data analyses. Responses from five (5) participants were excluded because they did not complete the 
entire questionnaire. After that, data were input into Statistical Package for the Social Science (SPSS) software for statistical analysis. In an attempt to assess construct validity of the pilot instrument, an exploratory factor analysis was performed. Exploratory factor analysis is most frequently used as a part of the instrument development process. The purpose of this factor analysis was to identify statements that were not contributing to the explanation of variations in information literacy skills. Result of running an exploratory factor analysis using principal component and characteristic rotation method yielded four (4) factors which collectively explained $50 \%$ of the total variance. The first factor accounted for $19 \%$ of the variance (eigenvalue= $18 \%$ ), the second factors explained $13.5 \%$ of the variance (eigenvalue $=8.76$ ), the third factor represented $7.66 \%$ of the variance (eigenvalue $=5.25$ ). For the fourth factor accounted $4.56 \%$ of the variance (eigenvalue $=6.53$ ).

The next step was to determine the internal consistency of the total scale as well as each of scales. Cronbach's internal reliability coefficient alpha is the most commonly accepted measure of internal consistency. Cronbach's alpha varies from zero (0) to one (1) which higher values of alpha indicates higher reliability of the instrument. The first scale presented good internal consistency for the reliability analysis that yielded an alpha coefficient value of 0.800 till 0.900 (Mohsen \& Reg, 2011). In general, Mohsen and Reg (2011) concluded that some of the researchers agree the result of reliability analysis for the Cronbach's Alpha value above 0.700 is acceptable. The score of Cronbach's alpha is 0.404 , which is an unacceptable value. Inspection of the internal reliability analysis revealed that dropping three items (S15, S18, and S22) from the scale had the effect of raising alpha coefficient from 0.300 to 0.404 , which is an acceptable level of internal consistency (Table 2). As a result, the number of valid and reliable items in the instrument decreased to only thirty seven (37) items.

Table 2: Internal Reliability Analysis for 'forty (40) items'

\begin{tabular}{|c|c|c|c|c|c|c|c|}
\hline No. & $\begin{array}{l}\text { Item } \\
\text { Nom }\end{array}$ & $\begin{array}{l}\text { Cronbach's Alpha if } \\
\text { item deleted }\end{array}$ & $\begin{array}{l}\text { ACRL IL } \\
\text { Standard }\end{array}$ & No. & $\begin{array}{l}\text { Item } \\
\text { Nom }\end{array}$ & $\begin{array}{l}\text { Cronbach's Alpha if } \\
\text { item deleted }\end{array}$ & $\begin{array}{l}\text { ACRL IL } \\
\text { Standard }\end{array}$ \\
\hline 1 & S1 & .343 & Standard 1 & 21 & S21 & .342 & Standard 1 \\
\hline 2 & S2 & .385 & Standard 1 & 22 & S22 & $* .406$ & Standard 3 \\
\hline 3 & S3 & .396 & Standard 2 & 23 & S23 & .341 & Standard 3 \\
\hline 4 & S4 & .351 & Standard 1 & 24 & S24 & .387 & Standard 3 \\
\hline 5 & S5 & .342 & Standard 2 & 25 & S25 & .319 & Standard 5 \\
\hline 6 & S6 & .395 & Standard 1 & 26 & S26 & .303 & Standard 2 \\
\hline 7 & S7 & .392 & Standard 2 & 27 & S27 & .373 & Standard 2 \\
\hline 8 & S8 & .339 & Standard 2 & 28 & S28 & .363 & Standard 2 \\
\hline 9 & S9 & .404 & Standard 3 & 29 & S29 & .319 & Standard 2 \\
\hline 10 & S10 & .391 & Standard 3 & 30 & S30 & .342 & Standard 3 \\
\hline 11 & S11 & .384 & Standard 2 & 31 & S31 & .350 & Standard 3 \\
\hline 12 & S12 & .356 & Standard 2 & 32 & S32 & .371 & Standard 3 \\
\hline 13 & S13 & .332 & Standard 3 & 33 & S33 & .391 & Standard 2 \\
\hline 14 & S14 & .327 & Standard 3 & 34 & S34 & .348 & Standard 3 \\
\hline 15 & S15 & $* .427$ & Standard 3 & 35 & S35 & .393 & Standard 1 \\
\hline 16 & S16 & .360 & Standard 3 & 36 & S36 & .350 & Standard 3 \\
\hline 17 & S17 & .404 & Standard 2 & 37 & S37 & .352 & Standard 5 \\
\hline 18 & S18 & $* .437$ & Standard 3 & 38 & S38 & .341 & Standard 5 \\
\hline 19 & S19 & .383 & Standard 2 & 39 & S39 & .381 & Standard 5 \\
\hline 20 & S20 & .373 & Standard 2 & 40 & S40 & .379 & Standard 5 \\
\hline
\end{tabular}


INTERNATIONAL JOURNAL OF ACADEMIC RESEARCH IN BUSINESS AND SOCIAL SCIENCES

Vol. 9, No. 13, Special Issue: Revolutionizing Education: Challenges, Innovation, Collaboration., 2019, E-ISSN: 2222-6990 @ 2019 HRMARS

The internal consistency coefficient of the second test was 0.517 , which is an unacceptable value. After examining the internal reliability analysis, it was decided to drop two (7) items from this item (S3, S6, S7, S9, S17, S19 and S35) which increased the Cronbach's alpha to a satisfactory value of 0.640 (Table 3).

Table 3: Internal Reliability Analysis for 'thirty seven (37) items'

\begin{tabular}{llll|llll}
\hline No. & Item & $\begin{array}{l}\text { Cronbach's } \\
\text { Alpha if item } \\
\text { deleted }\end{array}$ & $\begin{array}{l}\text { ACRL IL } \\
\text { Standard }\end{array}$ & No. & $\begin{array}{l}\text { Item } \\
\text { Nom }\end{array}$ & $\begin{array}{l}\text { Cronbach's } \\
\text { Alpha if item } \\
\text { deleted }\end{array}$ & $\begin{array}{l}\text { ACRL IL } \\
\text { Standard }\end{array}$ \\
\hline 1 & S1 & .486 & Standard 1 & 21 & S24 & .515 & Standard 3 \\
2 & S2 & .514 & Standard 1 & 22 & S25 & .450 & Standard 5 \\
3 & S3 & $* .523$ & Standard 2 & 23 & S26 & .445 & Standard 2 \\
4 & S4 & .493 & Standard 1 & 24 & S27 & .506 & Standard 2 \\
5 & S5 & .482 & Standard 2 & 25 & S28 & .496 & Standard 2 \\
6 & S6 & $* .525$ & Standard 1 & 26 & S29 & .458 & Standard 2 \\
7 & S7 & $* .520$ & Standard 2 & 27 & S30 & .480 & Standard 3 \\
8 & S8 & .486 & Standard 2 & 28 & S31 & .487 & Standard 3 \\
9 & S9 & $* .528$ & Standard 3 & 29 & S32 & .508 & Standard 3 \\
10 & S10 & .516 & Standard 3 & 30 & S33 & .512 & Standard 2 \\
11 & S11 & .510 & Standard 2 & 31 & S34 & .486 & Standard 3 \\
12 & S12 & .486 & Standard 2 & 32 & S35 & $* .522$ & Standard 1 \\
13 & S13 & .471 & Standard 3 & 33 & S36 & .490 & Standard 3 \\
14 & S14 & .471 & Standard 3 & 34 & S37 & .494 & Standard 5 \\
15 & S16 & .491 & Standard 3 & 35 & S38 & .479 & Standard 5 \\
16 & S17 & $* .527$ & Standard 2 & 36 & S39 & .511 & Standard 5 \\
17 & S19 & $* .518$ & Standard 2 & 37 & S40 & .511 & Standard 5 \\
18 & S20 & .503 & Standard 2 & & & & \\
19 & S21 & .475 & Standard 1 & & & & \\
20 & S23 & .489 & Standard 3 & & & & \\
\hline & & & & & & \\
\hline
\end{tabular}


INTERNATIONAL JOURNAL OF ACADEMIC RESEARCH IN BUSINESS AND SOCIAL SCIENCES

Vol. 9, No. 13, Special Issue: Revolutionizing Education: Challenges, Innovation, Collaboration., 2019, E-ISSN: 2222-6990 @ 2019 HRMARS

Table 4: Internal Reliability Analysis for 'thirty (30) items'

\begin{tabular}{llll|llll}
\hline No. & $\begin{array}{l}\text { Item } \\
\text { Nom }\end{array}$ & $\begin{array}{l}\text { Cronbach's } \\
\text { Alpha if item } \\
\text { deleted }\end{array}$ & $\begin{array}{l}\text { ACRL IL } \\
\text { Standard }\end{array}$ & No. & $\begin{array}{l}\text { Item } \\
\text { Nom }\end{array}$ & $\begin{array}{l}\text { Cronbach's } \\
\text { Alpha if item } \\
\text { deleted }\end{array}$ & $\begin{array}{l}\text { ACRL IL } \\
\text { Standard }\end{array}$ \\
\hline 1 & S1 & .613 & Standard 1 & 16 & S25 & .576 & Standard 5 \\
2 & S2 & .633 & Standard 1 & 17 & S26 & .583 & Standard 2 \\
3 & S4 & .620 & Standard 1 & 18 & S27 & .629 & Standard 2 \\
4 & S5 & .612 & Standard 2 & 19 & S28 & .620 & Standard 2 \\
5 & S8 & .616 & Standard 2 & 20 & S29 & .600 & Standard 2 \\
6 & S10 & $* .640$ & Standard 3 & 21 & S30 & .609 & Standard 3 \\
7 & S11 & .631 & Standard 2 & 22 & S31 & .613 & Standard 3 \\
8 & S12 & .605 & Standard 2 & 23 & S32 & .627 & Standard 3 \\
9 & S13 & .602 & Standard 3 & 24 & S33 & .627 & Standard 2 \\
10 & S14 & .584 & Standard 3 & 25 & S34 & .613 & Standard 3 \\
11 & S16 & .614 & Standard 3 & 26 & S36 & .620 & Standard 3 \\
12 & S20 & .625 & Standard 2 & 27 & S37 & .623 & Standard 5 \\
13 & S21 & .603 & Standard 1 & 28 & S38 & .609 & Standard 5 \\
14 & S23 & .622 & Standard 3 & 29 & S39 & .634 & Standard 5 \\
15 & S24 & $* .649$ & Standard 3 & 30 & S40 & .626 & Standard 5 \\
\hline
\end{tabular}

To determine the internal consistency of the third test, Cronbach's coefficient alpha was calculated, yielded a reliability estimate of 0.774 . Deletion of item S10 and S24 (Table 4) improved the reliability score slightly to 0.774 (Table 5). As a result, the totals of twenty eight (28) items valid and reliable items were remained in the instrument.

Table 5: Internal Reliability Analysis for 'twenty eight (28) items'

\begin{tabular}{llll|llll}
\hline No. & Item & $\begin{array}{l}\text { Cronbach's } \\
\text { Nomph if item } \\
\text { deleted }\end{array}$ & $\begin{array}{l}\text { ACRL IL } \\
\text { Standard }\end{array}$ & No. & $\begin{array}{l}\text { Item } \\
\text { Nom }\end{array}$ & $\begin{array}{l}\text { Cronbach's } \\
\text { Alpha if item } \\
\text { deleted }\end{array}$ & $\begin{array}{l}\text { ACRL IL } \\
\text { Standard }\end{array}$ \\
\hline 1 & S1 & .715 & Standard 1 & 15 & S26 & .674 & Standard 2 \\
2 & S2 & .727 & Standard 1 & 16 & S27 & .715 & Standard 2 \\
3 & S4 & .706 & Standard 1 & 17 & S28 & .695 & Standard 2 \\
4 & S5 & .704 & Standard 2 & 18 & S29 & .694 & Standard 2 \\
5 & S8 & .716 & Standard 3 & 19 & S30 & .702 & Standard 3 \\
6 & S11 & .713 & Standard 2 & 20 & S31 & .696 & Standard 3 \\
7 & S12 & .701 & Standard 2 & 21 & S32 & .674 & Standard 3 \\
8 & S13 & .682 & Standard 1 & 22 & S33 & .715 & Standard 2 \\
9 & S14 & .725 & Standard 3 & 23 & S34 & .695 & Standard 3 \\
10 & S16 & .709 & Standard 3 & 24 & S36 & .699 & Standard 3 \\
11 & S20 & .715 & Standard 2 & 25 & S37 & .722 & Standard 5 \\
12 & S21 & .703 & Standard 1 & 26 & S38 & .703 & Standard 5 \\
13 & S23 & .710 & Standard 3 & 27 & S39 & 0.704 & Standard 5 \\
14 & S25 & .667 & Standard 5 & 28 & S40 & 0.724 & Standard 5 \\
\hline
\end{tabular}




\section{Validation of the Scale}

The returned questionnaires from the pilot study were reviewed for incomplete or missing information before being entered into SPSS for statistical analysis. Five (5) questionnaires were eliminated due to insufficient data, leaving a final sample of thirty (30). Negatively worded statements were reversed during data input so that all statements were scored in the same direction. The Kaise-Meyer-Olkin (KMO) is a measure of sampling adequacy and varies between zero and one, with values greater than or equal to 0.60 used to indicate a good fit. In this study the value was 0.877 , suggesting that there was sampling adequacy. Additionally, significance of the Bartlett's Test of Sphericity (chi-square $=13100.00, \mathrm{df}=2321 \mathrm{p}<0.000$ ) indicated that the items contained adequate common variance to proceed with exploratory factor analysis.

Exploratory factor analysis with varimax rotation was performed then, in order to assess the construct validity of the instrument as well as to determine the appropriate number of factors and statements grouping in each of these factors. To produce meaningfully distinct factors, the principal axis method was used. Statements with factor loading less than 0.4 were dropped, leaving twenty eight (28) items. The initial analysis indicated four (4) factors with eigenvalues greater than 1.0. Accordingly, the items were forced into four (4) factors which accounted for $25.14 \%$ of the cumulative variance (Table 6).

Table 6: Descriptions of Standards

\begin{tabular}{lllll}
\hline Standards & Eigenvalues & \% of variance & Cumulative \% & No. of Items \\
\hline One (1) & 11.23 & 13.12 & 13.73 & 5 \\
Two (2) & 5.32 & 6.36 & 19.67 & 9 \\
Three (3) & 4.14 & 4.68 & 21.32 & 9 \\
Five (5) & 3.26 & 3.72 & 25.14 & 5 \\
\hline
\end{tabular}

The first factor consisted of five (5) items and accounted for $13.12 \%$ of the total variance (eigenvalue=11.23). The items within this factor had rotated factor loadings ranging from 0.424 to 0.587 (Table 7). This factor was labeled as standard one (1).

The second factor (eigenvalue=5.32), accounted for $6.36 \%$ of the total variance and was nine (9) items with factor loadings ranging from 0.454 to 0.627 (Table 8). This factor was labeled as standard two (2).

The third factor, identified as standard three (3), contained nine (9) items. These items explained 4.14 $\%$ of the total variance and had an eigenvalue of 4.14 . The items within the third factor had rotated factor loadings between 0.426 and 0.658 (Table 9).

The fourth factor comprised five (5) items and explained only $3.72 \%$ of the variance. The items within this factor exhibited rotated factor loadings ranging from 0.408 to 0.552 (Table 10) with eigenvalue of 3.26. This factor was named as standard five (5). 
INTERNATIONAL JOURNAL OF ACADEMIC RESEARCH IN BUSINESS AND SOCIAL SCIENCES

Vol. 9, No. 13, Special Issue: Revolutionizing Education: Challenges, Innovation, Collaboration., 2019, E-ISSN: 2222-6990 @ 2019 HRMARS

Table 7: Factor Loadings for 'Standards One'

\begin{tabular}{lll}
\hline Number & Item & Factor Loading \\
\hline 1. & (1) Types of source & 0.434 \\
2. & (3) Knowing source located & 0.523 \\
3. & (4) Limiting search & 0.424 \\
4. & (13) Knowing effective search terms & 0.587 \\
5. & (21) Knowing source located & 0.468 \\
\hline
\end{tabular}

Table 8: Factor Loadings for 'Standards Two'

\begin{tabular}{lll}
\hline Number & Item & Factor Loading \\
\hline 1. & (2) Searching for publication & 0.454 \\
2. & (5) Boolean operators & 0.624 \\
3. & (6) Boolean operators & 0.561 \\
4. & (8) Boolean operators & 0.495 \\
5. & (10) Knowing source purpose & 0.517 \\
6. & (17) Boolean operators & 0.499 \\
7. & (19) Knowledge of reference types & 0.588 \\
8. & (20) Knowledge of reference types & 0.627 \\
9. & (23) Searching for publication & 0.604 \\
\hline
\end{tabular}

Table 9: Factor Loadings for 'Standards Three'

\begin{tabular}{lll}
\hline Number & Item & Factor Loading \\
\hline 1. & (7) Refining the search & 0.524 \\
2. & (9) Using data from table & 0.579 \\
3. & (11) Accessing publication & 0.426 \\
4. & (12) Using information & 0.483 \\
5. & (14) Knowing effective search terms & 0.585 \\
6. & (15) Evaluating source credibility & 0.449 \\
7. & $(18)$ Using data from table & 0.572 \\
8. & (22) Using information & 0.658 \\
9. & (24) Using information & 0.647 \\
\hline
\end{tabular}

Table 10: Factor Loadings for 'Standards Five'

\begin{tabular}{lll}
\hline Number & Item & Factor Loading \\
\hline 1. & (16) Ethical, Plagiarism & 0.465 \\
2. & $(25)$ Knowledge of related source available & 0.514 \\
3. & $(26)$ Intellectual property & 0.408 \\
4. & $(27)$ Knowledge of related source available & 0.526 \\
5. & (28) Ethical, Plagiarism & 0.552 \\
\hline
\end{tabular}

The next step was to determine the internal consistency of the total scale as well as each of subscales. Cronbach's alpha varies from zero (0) to one (1) which higher values of alpha indicates higher 
reliability of the instrument. The first sub- scale presented good internal consistency for the reliability analysis that yielded an alpha coefficient value of 0.755 . Table 11 contains the alpha coefficients that would be generated if each item were to be deleted from the scale. According to this table, dropping anyone of the five (5) items would not significantly raise the value of alpha coefficient higher than the present value of 0.755 .

\begin{tabular}{|c|c|c|}
\hline Number & Scale Item & Alpha if item deleted \\
\hline 1. & 1 & 0.752 \\
\hline 2. & 3 & 0.745 \\
\hline 3. & 4 & 0.750 \\
\hline 4. & 13 & 0.749 \\
\hline 5. & 21 & 0.751 \\
\hline
\end{tabular}

The alpha coefficient for the second factor was 0.785 which indicates evidence of adequate internal consistency. Inspection of Table 12 revealed that deletion any of the nine (9) items would not increase the alpha coefficient of the sub-scale higher than the present value of 0.785 .

\begin{tabular}{|c|c|c|}
\hline Number & Scale Item & Alpha if item deleted \\
\hline 1. & 2 & 0.766 \\
\hline 2. & 5 & 0.782 \\
\hline 3. & 6 & 0.780 \\
\hline 4. & 8 & 0.758 \\
\hline 5. & 10 & 0.764 \\
\hline 6. & 17 & 0.757 \\
\hline 7. & 19 & 0.768 \\
\hline 8. & 20 & 0.783 \\
\hline 9. & 23 & 0.782 \\
\hline
\end{tabular}

To determine the internal consistency of the third factors, Cronbach's coefficient alpha was calculated, yielded a reliability estimate of 0.805. As a result, the totals of nine (9) valid and reliable items were remained in the third factor as shown in Table 13 which is the internal reliability analysis for standards three. 
INTERNATIONAL JOURNAL OF ACADEMIC RESEARCH IN BUSINESS AND SOCIAL SCIENCES

Vol. 9, No. 13, Special Issue: Revolutionizing Education: Challenges, Innovation, Collaboration., 2019, E-ISSN: 2222-6990 @ 2019 HRMARS

Table 13: Internal Reliability Analysis for 'Standards Three'

\begin{tabular}{lll}
\hline Number & Scale Item & Alpha if item deleted \\
\hline 1. & 7 & 0.789 \\
2. & 9 & 0.787 \\
3. & 11 & 0.771 \\
4. & 12 & 0.800 \\
5. & 14 & 0.802 \\
6. & 15 & 0.758 \\
7. & 18 & 0.786 \\
8. & 22 & 0.792 \\
9. & 24 & 0.780 \\
\hline
\end{tabular}

The alpha coefficient for the four factors was 0.815 which indicated a high degree of internal consistency. Dropping any one of the five (5) items would not significantly increase the value of alpha coefficient (Table 14).

Finally, the high value of alpha coefficient for each of the sub-scales as well as the total instrument $(\alpha=0.774)$ indicated acceptable internal consistency of the WebOPAC Training Information Literacy scale based on ACRL's IL standards (Table 15).

Table 14: Internal Reliability Analysis for 'Standards Five'

\begin{tabular}{lll}
\hline Number & Scale Item & Alpha if item deleted \\
\hline 1. & 16 & 0.811 \\
2. & 25 & 0.792 \\
3. & 26 & 0.812 \\
4. & 27 & 0.778 \\
5. & 28 & 0.798 \\
\hline
\end{tabular}

Table 15: Internal Reliability for Overall Scale and Sub-scales

\begin{tabular}{llll}
\hline Number & Sub- Scale & $\begin{array}{l}\text { Number } \\
\text { Item }\end{array}$ & $\begin{array}{l}\text { of } \\
\text { Alpha }\end{array}$ \\
\hline 1. & Standard One & 5 & 0.768 \\
2. & Standard Two & 9 & 0.765 \\
3. & Standard Three & 9 & 0.755 \\
4. & Standard Five & 5 & 0.738 \\
\hline Total & WebOPAC Training Information Literacy & 28 & 0.774 \\
& Scale & \\
\hline
\end{tabular}




\section{Discussions}

The study was conducted in order to develop and validate the WebOPAC Training Information Literacy Scale based on ACRL's information literacy (IL) standards. The development and validation of this scale followed a standard pattern for psychometric research and ACRL's IL Standards. In the first step, a list of sixty (60) potential key components was generated using different resources. Possible components were gleaned from literature review, existing instruments, interviews the expert librarians and interviews with degree students. The list of key components was sent to a panel of experts for their comments and feedbacks.

Based on the responses received from the experts, fifteen (15) items were eliminated from the list, and five (5) new components were added, leaving fifty (50) items. After that, a total of fifty (50) items were created with the respect to each of the items and were sent again to expert validation. Based upon the expert's comments, a pilot instrument comprising forty (40) items was developed. A pilot study was conducted during March 2014 at UiTM Kelantan branch as a sampled. A total of thirty (30) first year degree students took part in the pilot study.

In order to assess the validity of the instrument, several approaches were used included content, face and construct validations. Five (5) experts established content validity of the instrument and confirmed that the statements of the instrument appeared to measure the concept of information literacy skills. In order to assess the content validity of the instrument, it was presented to a panel of experts for suggestions and validation. Construct validity of the instrument was determined using an exploratory factor analysis. The Kaiser- Meyer-Olkin (KMO) measure of sampling adequacy (0.877) and Bartlett's Test of Sphericity (chi-square $=13100.000, \mathrm{df}=2321, \mathrm{p}<0.000$ ), indicated the suitability of the data for factor analysis. A group of twenty (20) first year degree students evaluated the instrument for face validity. Overall, they reported that they satisfied with the instrument it is easy to understand.

To determine the internal reliability of all sub-scales as well as the overall scale, Cronbach's coefficient alpha was calculated. Reliability analysis using Cronbach's alpha revealed thirty two (32) items which were subsequently eliminated which leave twenty eight (28) items. Dropping these items from three time test had the effect of raising alpha coefficient values of these items. In this study all instrument had alpha values above 0.7 as shown in Table 15, which were considered reliable. Also, the result alpha coefficient of 0.774 for overall items provided evidence of adequate internal consistency of the instrument.

Result for this study indicated that the newly developed instrument for WebOPAC Training Information Literacy Scale based on ACRL's IL standards, had satisfactory face, content, and construct validity as well as internal reliability. This instrument consisted of twenty eight (28) items and the detailed of each item are shown in Table 16. The students were given two hour class period for the test but the instrument should be completed within one hour. The test items in this scale used pictorial representations of objects and the reading level was suitable for university students. 
INTERNATIONAL JOURNAL OF ACADEMIC RESEARCH IN BUSINESS AND SOCIAL SCIENCES

Vol. 9, No. 13, Special Issue: Revolutionizing Education: Challenges, Innovation, Collaboration., 2019, E-ISSN: 2222-6990 @ 2019 HRMARS

Table 16: The ACRL's Information Literacy Competency Standards, Percentage, Question Number and Description of the Scale

\begin{tabular}{|c|c|c|c|}
\hline Standard & $\begin{array}{l}\text { Percentage } \\
\text { of item }\end{array}$ & $\begin{array}{l}\text { Question (Q) } \\
\text { Number }\end{array}$ & Description \\
\hline $\begin{array}{l}\text { Standard One (1) } \\
\text { Defines and } \\
\text { articulates the } \\
\text { nature and extent of } \\
\text { information needed }\end{array}$ & $\begin{array}{l}5 / 28 \\
17.8 \%\end{array}$ & $\begin{array}{l}\text { S1, S2, S4, S13, } \\
\text { S21 }\end{array}$ & $\begin{array}{l}\text { Items mapped to standard one } \\
\text { broadly assess students' knowledge of } \\
\text { identifying and distinguishing } \\
\text { between different types of sources } \\
\text { (i.e., research article, encyclopedia, } \\
\text { and dictionary). This includes: } \\
\text { - Type of source } \\
\text { - Knowing source located } \\
\text { - Limiting search } \\
\text { - Knowing effective terms } \\
\text { - Knowing source located }\end{array}$ \\
\hline $\begin{array}{l}\text { Standard Two (2) } \\
\text { Access needed } \\
\text { information } \\
\text { effectively and } \\
\text { efficiently }\end{array}$ & $\begin{array}{l}9 / 28 \\
32.2 \%\end{array}$ & $\begin{array}{l}\text { S5, S11, S12, } \\
\text { S20, S26, S27, } \\
\text { S28, S29, S33 }\end{array}$ & $\begin{array}{l}\text { Items mapped to standard three } \\
\text { broadly assess students' ability to use } \\
\text { and critically evaluate source } \\
\text { information. This includes: } \\
\text { - Boolean operators } \\
\text { - Searching for publication } \\
\text { - Accessing publication } \\
\text { - Knowledge of reference types }\end{array}$ \\
\hline $\begin{array}{l}\text { Standard Three (3) } \\
\text { Evaluates } \\
\text { information and its } \\
\text { sources critically and } \\
\text { incorporates } \\
\text { selected into his or } \\
\text { her knowledge base } \\
\text { and value system }\end{array}$ & $\begin{array}{l}9 / 28 \\
32.2 \%\end{array}$ & $\begin{array}{l}\text { S14, S16, S23, } \\
\text { S30, S31, S32, } \\
\text { S34, S36, S38 }\end{array}$ & $\begin{array}{l}\text { Items mapped to standard three } \\
\text { broadly assess students' ability to use } \\
\text { and critically evaluate source } \\
\text { information. This includes: } \\
\text { - Refining the search } \\
\text { - Using data from table } \\
\text { - Knowing source purpose } \\
\text { - Using information } \\
\text { - Evaluating source credibility }\end{array}$ \\
\hline $\begin{array}{l}\text { Standard Five } \\
\text { Understand many of } \\
\text { the ethical, legal, and } \\
\text { socio-economic } \\
\text { issues surrounding } \\
\text { information and } \\
\text { information } \\
\text { technology }\end{array}$ & $\begin{array}{l}5 / 28 \\
17.8 \%\end{array}$ & $\begin{array}{l}\text { S25, S37, S38, } \\
\text { S39, } \\
\text { S40 }\end{array}$ & $\begin{array}{l}\text { Items mapped to standard five broadly } \\
\text { assess student's understanding of } \\
\text { ethical and legal issues regarding the } \\
\text { use of information from a source. This } \\
\text { includes: } \\
\text { - Ethical, Plagiarism } \\
\text { - Intellectual property } \\
\text { - Knowledge of related source } \\
\text { available }\end{array}$ \\
\hline
\end{tabular}


Regarding to the scale result, the total of students score (performance percentage) was calculate based on the combination of the standards as in the scale's items. Based on the report of IL's Test Manual by Swain et al., (2014) two (2) performance standards were set. The first standard differentiated examinees that were considered 'Proficient' from those that were 'Below Proficient'. The second standard differentiated those who were advanced from those that were 'Proficient'. Table 17 describes the details of the performance standards of Information Literacy Skills.

Table 17: The Performance Standard of Information Literacy Skills

\begin{tabular}{|c|c|c|}
\hline $\begin{array}{l}\text { Performance } \\
\text { Standard }\end{array}$ & $\begin{array}{l}\text { Performanc } \\
\text { e } \\
\text { Percentage }\end{array}$ & Describition of Performance Level \\
\hline $\begin{array}{l}\text { Below } \\
\text { Proficient }\end{array}$ & $<65 \%$ & \\
\hline Proficient & $>65 \%$ & $\begin{array}{l}\text { The student who is Proficient is able to: } \\
\text { - Describe how libraries are organized } \\
\text { - Define major library services } \\
\text { - Choose the appropriate type of reference } \\
\text { - } \text { source for a particular information need. } \\
\text { - Employ basic database search strategies } \\
\text { - Locate a variety of sources in a library or online } \\
\text { - Discriminate between scholarly and popular } \\
\text { - } \text { publications }\end{array}$ \\
\hline Advanced & $>90 \%$ & $\begin{array}{l}\text { The student who is Advanced is able to attain the } \\
\text { criteria for Proficient and: } \\
\text { - Modify and improve search strategies to } \\
\text { retrieve better results } \\
\text { - Employ sophisticated database search } \\
\text { strategies } \\
\text { - Interpret information in a variety of sources } \\
\text { - Evaluate information in terms of purpose, } \\
\text { - } \text { authority and reliability } \\
\text { issues relating to information access }\end{array}$ \\
\hline
\end{tabular}


INTERNATIONAL JOURNAL OF ACADEMIC RESEARCH IN BUSINESS AND SOCIAL SCIENCES

Vol. 9, No. 13, Special Issue: Revolutionizing Education: Challenges, Innovation, Collaboration., 2019, E-ISSN: 2222-6990 @ 2019 HRMARS

\section{Conclusion}

Finally, a valid and reliable 28-item WebOPAC Training Information Literacy Scale was developed which has the capability to access information literacy skills among library users in using WebOPAC system. In addition, this scale has been developed according to ACRL's Information Literacy Competency Standards for Higher Education standards. Furthermore, this scale could be a guideline to future information professionals, librarians, and researchers in measuring individual's information literacy skills during WebOPAC teaching and learning sessions. The future research from this study is to investigate the effects of WebOPAC Training Information Literacy Scale on information literacy (IL) skills development among students in Malaysian public universities.

\section{Acknowledgements}

This study is supported through the Academic \& Research Assimilation Scheme (ARAS) Phase 2/2016 granted from the Universiti Teknologi MARA, Malaysia (600-IRMI: 5/3/ARAS (0144/2016)).

\section{Corresponding Author}

Mohd Nasir Ismail, Faculty of Information Management, Universiti Teknologi MARA, Malaysia.

E-mail: nasir733@uitm.edu.my

\section{References}

ACRL. (2014). Framework for information literacy for higher education (June 2014 draft).

ACRL. (2011). Standards for libraries in higher education. Retrieved from http://www.ala.org/acrl/ standards/standardlibraries

ACRL. (2000). Information literacy competency standards for higher education. Retrieved from http://www.ala.org/acrl/standards/standardlibraries

Ali, R., Abu-hassan, N., Md Daud, M. Y., \& Jusoff, K. (2010). Information literacy skills of engineering students. International of Research and Reviews in Applied Science, 5(3), 264-270.

Anunobi, C., \& Udem, O. K. (2014). Information literacy competencies: A conceptual analysis. Journal of Applied Information Science and Technology, 7(2), 64-80.

Baro, E., \& Keboh, T. (2012). Teaching and fostering information literacy programmes: A survey of five university libraries in Africa. The Journal of Academic Librarianship, 38(5), 311-315. https://doi.org/10..1016/j.acalib.2012

Baroutian, S., \& Kensington-Miller, B. (2015). Information literacy: The impact of a hands-on workshop for international postgraduate students. Education for Chemical Engineers, 14(6), 16-23. https://doi.org/10.1016/j.ece.2015.10.001

Cordell, R. M. (2013). Information literacy and digital literacy. Communications in Information Literacy, 7(2), 126-136.

Derakhshan, M., Hassanzadeh, M., \& Nazari, M. (2015). Developing information literate librarians: A study of LIS academics pedagogical approaches in the development of information literacy competencies. Journal of Academic Librarianship, 777-785.

https://doi.org/10.1016/j.acalib.2015.08.021

Edzan, N. N. (2008). Information literacy development in Malaysia: A review, information literacy development in Malaysia, 58, 265-280. 
INTERNATIONAL JOURNAL OF ACADEMIC RESEARCH IN BUSINESS AND SOCIAL SCIENCES

Vol. 9, No. 13, Special Issue: Revolutionizing Education: Challenges, Innovation, Collaboration., 2019, E-ISSN: 2222-6990 @ 2019 HRMARS

Enterprises, C. (2012). Results of the Standardized Assessment of Information Literacy Skills (SAILS) for University of Pittsburgh. Pittsburgh: Carrick Enterprises, Inc Publisher.

Erfanmanesh, M., Abrizah, A. \& Karim, N. H. A (2012). Development and validation of the information seeking anxiety scale. Malaysian Journal of Library \& Information Science, 17(1), 21-39.

Fister, B. (2015). The liminal library: Making our libraries sites of transformative learning. The Liminal Library. Newcastle University: LILAC Publisher.

Forster, M. (2013). A phenomenographic investigation into Information Literacy in nursing practice preliminary findings and methodological issues. Nurse Education Today, 33(10), 1237-1241. https://doi.org/10.1016/j.nedt.2012.05.027

Grau, G. J., Archambault, S. G., Acosta, E. S., \& Mclean, L. (2016). Patience, persistence, and process: Embedding a campus-wide information literacy program across the curriculum. The Journal of Academic Librarianship, 42(6), 750-756. https://doi.org/10.1016/j.acalib.2016.10.013

Gregory, A. S., \& Broussard, M. J. S. (2011). Unraveling the 'Mystery' of the library: A 'Big Games' approach to library orientation. Proceedings of Association of College and Research Libraries (ACRL) Conference, (pp. 471-476). Philadelphia, Pennsylvania.

Gross, M., \& Latham, D. (2009). Undergraduate perceptions of information literacy: Defining, attaining, and self-assessing skills. College and Research Libraries. Retrieved from http://diginole.lib.fsu.edu/islandora/object/fsu\%3A207203

Gullikson, S. (2006). Faculty perceptions of ACRL's information literacy competency standards for higher education. The Journal of Academic Librarianship, 32(6), 583-592. http://doi.org/10.1016/j.acalib.2006.06.001

Husaini, H., Aziz, R. A., Karim, M. D. A., Jamin, J., \& Saad, D. M. S. M. (2011). Keperluan modul literasi maklumat di perpustakaan akademik di Malaysia: Kajian kes (pp. 267-287).

Information Literacy Standards Committee, A. (2012). The charge of the ACRL information literacy competency standards review task force. http://connect.ala.org/node/140464

Jyoon, M. C. L., \& Ibrahim, M. Y. (2015). Information literacy for sustainable advancement: Malaysian experience (pp.1-11). http://myrepositori.pnm.gov.my/bitstream/123456789/4027/1/ CONSALXVI_ChinL_Yazidlbrahim.pdf

Kim, S. U., \& Shumaker, D. (2015). Student, librarian, and instructor perceptions of information literacy instruction and skills in a first year experience program: A case study. The Journal of Academic Librarianship, 41(4), 449-456. https://doi.org/10.1016/j.acalib.2015.04.005

Lanning, S., \& Mallek, J. (2017). Factors influencing information literacy competency of college students. Journal of Academic Librarianship, 43(5), 443-450. https://doi.org/10.1016/j.acalib.2017.07.005

Loo, J. L., Eifler, D., Smith, E., Pendse, L., He, J., Sholinbeck, M., Dupuis, E. A. (2016). Flipped instruction for information literacy: Five instructional cases of academic librarians. Journal of Academic Librarianship, 42(3), 273-280. https://doi.org/10.1016/j.acalib.2016.03.001

Lorin, A., \& Krathwohl, D. (2001). A taxonomy for learning, teaching and assessing: A revision of bloom's taxonomy. In Blooms (pp. 7-8).

Mackey, T. P., \& Jacobson, T. E. (2011). Teaching information literacy online. New York: Neal-Schuman Publishers, Inc. 
INTERNATIONAL JOURNAL OF ACADEMIC RESEARCH IN BUSINESS AND SOCIAL SCIENCES

Vol. 9, No. 13, Special Issue: Revolutionizing Education: Challenges, Innovation, Collaboration., 2019, E-ISSN: 2222-6990 @ 2019 HRMARS

Magnuson, M. L. (2013). Web 2.0 and information literacy instruction: Aligning technology with ACRL standards. Journal of Academic Librarianship, 39(3), 244-251. http://doi.org/10.1016/j.acalib.2013.01.008

Maitaouthong, T., Tuamsuk, K., \& Tachamanee, Y. (2012). The roles of university libraries in supporting the integration of information literacy in the course instruction. Malaysian Journal of Library and Information Science, 17(1), 51-64.

Martin, J. (2013). Refreshing information literacy : Learning from recent British information literacy models. Communications in Information Literacy, 7(2), 114-127.

Michalak, R., Rysavy, M. D. T., \& Wessel, A. (2017). Students' perceptions of their information literacy skills: the confidence gap between male and female international graduate students. The Journal of Academic Librarianship, 43(2), 100-104.

https://doi.org/10.1016/j.acalib.2017.02.003

Mittermeyer, D., \& Quirion, D. (2003). Information literacy: Study of incoming first-year undergraduates in Quebec. In Conference of Rectors and Principals of Quebac Universities (pp.1-107). Retrieved from http://www.crepuq.qc.ca/documents/bibl/formation/studies_Ang.pdf

Mohsen, T., \& Reg, D. (2011). Post-examination analysis of objectives tests. Medial Teacher, 33(6), 447-458. Doi: 10.3109/0142159X.2011.564682

Nurfaezah Mamat, Mohd Nasir Ismail \& Adnan Jamaludin. (2014). Deficiencies in library orientation programs at Malaysian academic libraries. International Journal of Library and Information Studies (IJLIS), 4(3), 1-8.

Ramli, N., Fun, C. S., \& Idris, F. (2009). Kajian kepuasan pelanggan terhadap perkhidmatan perpustakaan universiti awam di Malaysia. Jurnal Pengurusan, 28, 23-43.

Ranaweera, P. (2010). Information literacy programmes conducted by the universities in Sri Lanka. Journal of the University Librarians Association of Sri Lanka, 14(1), 61-75.

Rice, S., \& Gregor, M. N. (2013). This library orientation is fun!: Building a successful virtual tour experience for students. In ACRL (pp. 583-588).

Rohatgi, A., Scherer, R., \& Hatlevik, O. E. (2016). The role of ICT self-efficacy for students ICT use and their achievement in a computer and information literacy test. Journal Computers and Education, 102(6), 103-116. https://doi.org/10.1016/j.compedu.2016.08.001

Saunders, L., Severyn, J., Freundlich, S., Piroli, V., \& Munderback, J. S. (2016). Assessing graduate level information literacy instruction with critical incident questionnaires. The Journal of Academic Librarianship, 42(6), 655-663. https://doi.org/10.1016/j.acalib.2016.08.008

Shao, X., \& Purpur, G. (2016). Effects of information literacy skills on student writing and course performance. Journal of Academic Librarianship, 42(6), 670-678. https://doi.org/10.1016/j.acalib.2016.08.006

Shariman, T. P. N. T., Razak, N. A., \& Noor, N. F. M. (2014). The multimodal literacy practices of Malaysian youths in a digital environment. Procedia - Social and Behavioral Sciences, 141, 1171-1176. https://doi.org/10.1016/j.sbspro.2014.05.199

Swain, M., Sundre, D. L., \& Clarke, K. (2014). The Information Literacy Test (ILT) test manual. Madison Assessment Publisher.

Syamalamba, R. (2011). Information literacy programmes for undergraduate students. International Journal of Digital Library Services, 1(1), 49-61. 
Team, Q. I. (2009). Knowledge is power: Improving students' information literacy skills. Louisiana: Spring Publishers.

Thanuskodi, S. (2013). ICT literacy among library professionals in the engineering college libraries of Tamil Nadu: An analytical. International Journal of Digital Library Services, 1(2), 131-141.

Ukachi, N. B. (2015). Exploration of information literacy skills status and impacts on the quality of life of artisans in Lagos, Nigeria. The Electronic Library, 116(9/10), 578-587. https://doi.org/10.1108/IJBM-07-2013-0069

Wilson, L. O. (2016). Understanding the new version of Bloom's taxonomy. Boston, MA: Allyn \& Bacon. Wise, S. L., Cameron, L., Yang, S.-T., \& Davi, S. L. (2011). The information literacy test (ILT) test manual. The Center For Assessment \& Research Studies. Madison Assessment LLC Publisher. http://www.madisonassessment.com

Wu, M. Der., \& Ssu-Tsen, Y. (2012). Effects of undergraduate student computer competence on usage of library electronic collections. Journal of Library \& Information Studies, 10(1), 1-17. Retrieved from

http://search.ebscohost.com/login.aspx?direct=true \&db=lih\&AN=82830976\&site=eds-live 